Abstracta Iranica Abstracta Iranica

Revue bibliographique pour le domaine irano-aryen

Volume 31 | 2011

Comptes rendus des publications de 2008

\title{
Atti di Mar Mari. Brescia, Paideia, 2008, 234 p. (Testi del Vicino Oriente Antico 7. Letteratura della Siria cristiana 2)
}

\section{Rédaction}

\section{(2) OpenEdition}

1 Journals

\section{Édition électronique}

URL : http://journals.openedition.org/abstractairanica/39679

DOI : 10.4000/abstractairanica.39679

ISSN : 1961-960X

Éditeur :

CNRS (UMR 7528 Mondes iraniens et indiens), Éditions de l'IFRI

\section{Édition imprimée}

Date de publication : 15 mai 2011

ISSN : 0240-8910

Référence électronique

Rédaction, «Atti di Mar Mari. Brescia, Paideia, 2008, 234 p. (Testi del Vicino Oriente Antico 7. Letteratura della Siria cristiana 2) », Abstracta Iranica [En ligne], Volume 31 | 2011, document 223, mis en ligne le 11 octobre 2012, consulté le 28 septembre 2020. URL : http://journals.openedition.org/abstractairanica/ 39679 ; DOI : https://doi.org/10.4000/abstractairanica.39679

Ce document a été généré automatiquement le 28 septembre 2020.

Tous droits réservés 


\section{Atti di Mar Mari. Brescia, Paideia, 2008, 234 p. (Testi del Vicino Oriente Antico 7. Letteratura della Siria cristiana 2)}

\section{Rédaction}

L'A. n'a pas cherché bien loin pour trouver sa source d'inspiration : cet ouvrage traduit presque intégralement en italien - sans toujours les citer - les travaux de C. et F. Jullien sur les Actes de Mar Mari (CSCO 603, script. syr. Textus $235 ; 602$, script. syr. Versio $234 ; 604$, Subsidia 114, Louvain, 2003) et sur les traditions apostoliques en Iran (Apôtres des confins. Processus missionnaires chrétiens dans l'empire iranien, (Res Orientales XV), Bures-surYvette, 2002). On ne peut que regretter pareille méthode, dommageable pour l'auteur.

\section{INDEX}

Thèmes : 6.3. Autres religions

\section{AUTEURS}

\section{RÉDACTION}

Directeur de la revue et secrétariats (Paris et Téhéran) 